KS. WITOLD JEMIELITY (Łomża)

\title{
WSPÓŁISTNIENIE NARODOWOŚCI I WYZNAŃ WE WSCHODNIM REJONIE KRÓLESTWA POLSKIEGO
}

\section{Wstęp}

Jednym z ośmiu województw Królestwa Polskiego było województwo augustowskie. W 1866 r. z jego obszaru powstały gubernie łomżyńska i suwalska. Autor zamierza omówić współżycie narodowości i wyznań właśnie na tym terenie. Mieszkali tutaj Polacy, Litwini, Rusini, Rosjanie, Niemcy i Żydzi, a pod względem wyznaniowym: rzymskokatolicy, grekokatolicy, prawosławni, protestanci i starozakonni. Województwo augustowskie obejmowało części Mazowsza, Podlasia i Wielkiego Księstwa Litewskiego, z czego wynikała wielość narodowości i wyznań.

Temat dotyczy wprawdzie wschodniego rejonu, ale pośrednio przedstawia sytuację w całym Królestwie Polskim, bowiem przepisy rządowe i kościelne odnosiły się do wszystkich województw. Nikt dotąd nie zajmował się wprost tym zagadnieniem.

\section{Narodowości i wyznania}

\section{Polacy - rzymskokatolicy}

W 1897 r. w guberni łomżyńskiej Polacy stanowili 77,3\% ogółu ludności, a w guberni suwalskiej: w powiecie augustowskim - $62 \%$, kalwaryjskim - $3 \%$, mariampolskim $-2 \%$, sejneńskim $-20 \%$, suwalskim $-64 \%$, władysła- 
wowskim $-0 \%$ i wiłkowyskim $-2 \%^{1}$. Byli rzymsko-katolikami, należeli do diecezji augustowskiej, czyli sejneńskiej, oraz do diecezji płockiej².

\section{Litwini - rzymskokatolicy}

Na przełomie stulecia w guberni suwalskiej Litwini stanowili w powiecie augustowskim $-0 \%$, kalwary jskim $-77 \%$, mariampolskim $-79 \%$, sejneńskim $-60 \%$, suwalskim $-8 \%$, władysławowskim $-80 \%$ i wiłkowyskim $-70 \%^{3}$. Litwini i Polacy należeli do tych samych parafii, co ich do siebie zbliżało, ale pod koniec XIX wieku rodziło także i napięcia. Wówczas wśród Litwinów nastąpiło odrodzenie narodowe, które przybrało charakter ludowy. Wielką rolę w budzeniu świadomości odegrali księża litewscy. Miasto biskupie Sejny stało się ośrodkiem ruchu litewskiego, zwłaszcza po 1904 r., kiedy rząd zezwolił na używanie w druku czcionki łacińskiej

\section{Rusini - grekokatolicy}

$\mathrm{Na}$ obszarze województwa augustowskiego było dziewięć parafii unickich. Po 1866 r. dwie znajdowały się w guberni łomżyńskiej, pozostałe w guberni suwalskiej; razem liczyły ponad jedenaście tysięcy wiernych. Unici i łacinnicy mieszkali często w tych samych wsiach. Ludność ruska zapominała rodzimego języka, księża uniccy głosili kazania po polsku. W wyniku kasaty Unii w 1875 r. oficjalnie nie było grekokatolików. Po ukazie tolerancyjnym z 1905 r. większość unitów przeszła na obrządek łaciński ${ }^{5}$.

1 E. Kaczyńska, Spoteczeństwo i gospodarka pótnocno-wschodnich ziem Królestwa Polskiego w okresie rozwoju kapitalizmu, Warszawa 1974, s. 39, 41.

2 W. Jemielity, Diecezja augustowska czyli sejneńska w latach 1818-1872, Lublin 1972, s. 1 i n.; idem, Zarys dziejów diecezji augustowskiej czyli sejneńskiej, Lithuania 2(1995)99.

3 E. Kaczyńska, Gubernia suwalska w świetle oficjalnych danych statystycznych $w$ latach 1866-1914, w: Studia i materiały do dziejów Suwalszczyzny, Białystok 1965, s. 249.

4 B. Makowski, Litwini w Polsce 1920-1939, Warszawa 1986, s. 13.

5 W. Jemielity, Dekanat unicki augustowski w XIX i na poczatku XX wieku, w: Materiaty do dziejów społeczno-religijnych w Polsce, Lublin 1974, s. 157 i n.; idem, Augustowski unicki dekanat, w: Z dziejów chrześcijaństwa w Augustowie, Seria Episteme 2(1999)43-80; idem, Kasata Unii w dekanacie augustowskim, w: Metraštis, Vilnius 1998, s. 387-393 po litewsku, s. 395-403 po polsku. 


\section{Rosjanie - prawosławni}

Do powstania styczniowego wyznawcy prawosławia byli nieliczni w województwie augustowskim. Autor zajmował się szczegółowo dziekanatem prawosławnym, który pokrywał się z gubernią łomżyńską. $\mathrm{Na}$ jej terenie od 1834 r. była tylko jedna cerkiew wojskowa w Łomży. W 1858 r. przeszła ona pod zarząd biskupa diecezjalnego i wówczas powstała parafia. Stopniowo tworzono inne parafie: w 1878 r. w Grajewie, w 1904 r. - Ostrowi, w 1905 r. - Kolnie, w 1906 r. - Łapach. W 1870 r. do parafii w Łomży, która obejmowała zasięgiem terytorium guberni, należały 672 osoby, a w 1913 r. na tym samym terenie, już w kilku parafiach, mieszkało 7333 prawosławnych. Najwięcej było policjantów i urzędników, którzy osiedlali się w miastach i siedzibach gmin. W 1897 r. prawosławni stanowili 5\% ogółu ludności guberni łomżyńskiej. Podczas pierwszej wojny światowej większość Rosjan opuściła Królestwo Polskie. W 1921 r. na terenie byłej guberni łomżyńskiej pozostały 1574 osoby wyznania prawosławnego, głównie rzemieślnicy i pracownicy kolei żelaznej ${ }^{6}$.

\section{Niemcy - protestanci i katolicy}

W 1897 r. w guberni łomżyńskiej Niemcy stanowili 0,4\% ogółu ludności, a w guberni suwalskiej: w powiecie augustowskim $-16 \%$, kalwaryjskim $-4 \%$, mariampolskim $-7 \%$, sejneńskim $-1 \%$, suwalskim $-7 \%$, władysławowskim $-10 \%$ i wiłkowyskim - 18\%. Do pierwszej guberni przybyli dopiero w XIX wieku, w drugiej mieszkali od dawna, najliczniej w bezpośrednim sąsiedztwie Prus. W guberni łomżyńskiej główne skupisko Niemców było w powiecie ostrowskim, w gminach Jasienica i Długosiodło. W pierwszej gminie w 1825 r. mieszkało 239 katolików i 866 ewangelików, w 1911 r. - 2227 ewangelików, w 1921 r. - 691 ewangelików. W gminie Długosiodło przed pierwszą wojną światową było 1060 ewangelików, z których w $1921 \mathrm{r}$. pozostało 489 osób. W powiecie łomżyńskim ewangelicy mieszkali w gminie Szumowo, we wsi Srebrny Borek: w 1822 r. - 400, w 1839 r. - 348, w 1902 r. - 480, w 1921 r. - 221 osób. Ponadto ewangelicy byli w miastach, na przykład w 1913 r. w Łomży - 339, w Łapach - 230, w Jedwabnem - 131. W 1921 r. w powiecie kolneńskim na 200 ewangelików, do narodo-

6 W. Jemielity, Eomżyński Dziekanat Prawosławny, Studia Teologiczne 14 (1996) 
wości niemieckiej przyznawało się 7 osób, w powiecie ostrowskim na 1219 - 404, w powiecie łomżyńskim na 758 - 289 osób?

W guberni suwalskiej w $1904 \mathrm{r}$. istniały parafie ewangelickie w następujących miejscowościach: w Suwałkach z filiami w Augustowie i Sejnach, Wierzbołowie z filią we Władysławowie, Wiżajnach z filią w Wisztyńcu, Mariampolu z filiami w Kalwarii, Serejach i Wiłkowyszkach, Gudelach z filią w Prenach, Szakach z filią w Sudargach. Była również parafia ewangelicko-reformowana w Serejach ${ }^{8}$.

\section{6. $\dot{Z} y d z i$}

W 1897 r. Żydzi stanowili w guberni łomżyńskiej 15,8\% ogółu ludności, w guberni suwalskiej: w powiecie augustowskim $-16 \%$, kalwaryjskim $-14 \%$, mariampolskim $-11 \%$, sejneńskim - 16\%, suwalskim - $16 \%$, władysławowskim $-10 \%$ i wiłkowyskim - 9\%. Zamieszkiwali głównie miasta i większe osady. W 1890 r. w miastach Królestwa Polskiego Żydzi stanowili 50\% ludności, w gminach $8 \%$, zaś w samej guberni suwalskiej procent ten wynosił odpowiednio $70 \%$ i $9,5 \%$ ogółu ludności ${ }^{9}$.

\section{Kontakty między katolikami}

\section{Parafie mieszane polsko-litewskie}

$\mathrm{Na}$ początku XX wieku szczególnego znaczenia nabrała, dojrzewająca już od dawna, sprawa języka nabożeństw w parafiach mieszanych polsko-litewskich. W świątyniach ogniskowało się życie duchowe ludności, kościół więc mógł‘stać się ośrodkiem postępującej polonizacji bądź ostoją kształtującej się i umacniającej tożsamości litewskiej ${ }^{10}$.

W 1898 r. biskup sejneński Antoni Baranowski sporządził ankietę na temat życia religijnego w parafiach, pytał między innymi o język rodzimy ludności. Biskup ten nie ingerował w sprawy językowe, a w dekretach wizyta-

7 W. Jemielity, Kościót Ewangelicko-Augsburski w Eomżyńskiem 1795-1940, w: Na przetomie stuleci. Naród - Kościót - Państwo w XIX i XX wieku, Lublin 1997, s. 415.

8 W. Jemielity, Szkolnictwo w guberni suwalskiej, Suwałki 1997, s. 108.

9 E. Kaczyńska, Społeczeństwo, s. 39.

10 P. Łossowski, Kwestia przynależności państwowej Sejneńszczyzny w latach 19181920, w: Materiaty do dziejów ziemi sejneńskiej, t. 1, Białystok 1963, s. 354 . 
cyjnych zaznaczał, by podczas nabożeństw niedzielnych zachowywać dawne zwyczaje i nic nie zmieniać bez zgody władzy diecezjalnej. Właśnie w tym czasie przetłumaczono na język litewski pieśń religijną Święty Boże. Niektórzy księża uznali, że mogá śpiewać suplikacje po litewsku. Po intonacji przez księdza Polacy śpiewali po dawnemu, sprawa trafiła do biskupa, który orzekł, by zachować język polski ${ }^{11}$.

$\mathrm{Z}$ odpowiedzi ankietowych wynika, że nawet przy niewielkiej liczbie Polaków w parafii mieszanej język polski dominował wyraźnie w śpiewach godzinek, różańca, suplikacji, kazaniach głoszonych przez księży, zwłaszcza w święta doroczne; językiem liturgicznym była łacina. Litwini uznali ten stan rzeczy za krzywdzący i to stało się zarzewiem narastającego antagonizmu polsko-litewskiego. W parafii Berżniki doszło do bójek w kościele i z tego powodu na trzy lata zamknięto świątynię. W 1907 r. dla wsi litewskich utworzono parafię w Kuciunach, dla Polaków wznowiono nabożeństwa w Berżnikach. Bójki, ale poza kościołem, zdarzyły się również w Kalwarii. Administrator diecezji, ks. Józef Antonowicz, ustalił szczegółowy porządek modłów dla obu narodowości i przywrócił tam spokój. Podobnie uczynił w parafiach: Lubowie, Olwicie, Smolanach, Wisztyńcu i innych mieszanych. Wszędzie chodziło o język nabożeństw, a nie o sprawy wiary i obyczajów; były to spory narodowościowe, nie religijne ${ }^{12}$.

Alumni obu narodowości uczyli się wspólnie. Wykładano zasadniczo po łacinie, podobnie jak w innych seminariach duchownych. Wśród alumnów przeważali liczebnie uczniowie gimnazjum w Mariampolu, a więc Litwini, na przykład w 1865/66 r. było ich 46 z Mariampola na ogólną liczbę 67. Również uczniowie gimnazjum suwalskiego mogli być narodowości litewskiej: w 1865/66 - sześciu. Pod koniec XIX wieku profesorami seminarium sejneńskiego byli głównie Litwini ${ }^{13}$. Tymczasem w pierwszej połowie XIX wieku przeważali duchowni pochodzenia polskiego i nawet nie znając języka litewskiego, byli proboszczami na Litwie. Pod koniec stulecia zdecydowaną większość stanowili Litwini, którzy znali język polski, pracowali oni także na

11 W. Jemielity, Biskup sejneński Antoni Baranowski, w: Biskup Antoni Baranowski (Antanas Baranauskas) 1835-1902. Orędownik pojednania litewsko-polskiego, Warszawa 1998, Wydawnictwo Sejmowe, s. 44-53.

12 W. Jemielity, Język nabozienstw $w$ parafiach mieszanych polsko-litewskich przed I wojna światowq, w: Przeszłość natchnieniem dla teraźniejszości, Ełk 1996, s. 259 i n. Por. idem, Parafia jako wspólnota mieszkańców, w: Centra i peryferie, pod red. B. Gołębiowskiego, Łomża 1999, s. 144-151.

13 W. Jemielity, Seminarium Duchowne w Sejnach 1826-1914, Acta Baltico-Slavica 28(1988)193. 
Mazowszu i Podlasiu. Dwaj ostatni biskupi diecezji sejneńskiej, Antoni Baranowski (1897-1902) i Antoni Karaś (od 1910), też byli Litwinami. Wydaje się, że współżycie księży obu narodowości było poprawne ${ }^{14}$.

\section{Niemcy i Polacy}

W 1825 r. proboszcz parafii Jasienicy, pisząc do biskupa, wymienił „kolonistów rzymskokatolickich i protestanckich", na przykład w Kolonii Kowalówka były 4 rodziny katolickie i 1 mieszana, w Kolonii Pęchratka 5 rodzin katolickich i 2 mieszane, w Kolonii Paproć Duża 7 rodzin katolickich; razem było 239 katolików. Nie znali języka polskiego, ale ciążyli do parafii polskiej w Jasienicy. Po ich licznych prośbach do biskupa płockiego w Jasienicy objął stanowisko wikariusza nowo wyświęcony ksiądz Antoni Hochwald, znający język niemiecki; potem został on proboszczem w Jasienicy. Katolicy narodowości niemieckiej łączyli się z miejscową ludnością. Nawet władze carskie dostrzegały w nich mniej obcego ducha niż u ewangelików. W 1915 r. naczelnik powiatu ostrowskiego stwierdził, iż w gminie Jasienicy żyło około stu takich rodzin katolickich, mówiących po polsku, i- jak sądził - nie podlegających wysyłce do Rosji. Uważał ich raczej za „Niemców - kolonistów”; tymczasem porobiono ich spisy. Gubernator łomżyński zwrócił się do senatora Lubimowa, który zwolnił owe rodziny od wysyłki do Cesarstwa Rosyjskiego. Naczelnik powiatu ostrowskiego inaczej oceniał kolonistów wyznania protestanckiego: mówili oni bowiem po niemiecku, separowali się od miejscowej ludności, utrzymywali kontakty z mieszkańcami w Niemczech, zawsze ciążyli ku tamtym ${ }^{15}$.

Wspólne wyznanie katolickie zbliżało mieszkańców przy granicy Królestwa Polskiego i Prus. W 1825 r. biskup Augustyn Polikarp Marciejewski pisal, że katolicy w Prusach „od wieków w religijnych potrzebach do nas byli przyzwyczajeni". Przybywali do nadgranicznych parafii polskich głównie na spowiedź wielkanocną albo księża jechali na kilka dni do Prus. Po powstaniu styczniowym zerwały się wszelkie kontakty ${ }^{16}$.

14 W. Jemielity, Diecezja, s. 135

15 W. Jemielity, Kościót Ewangelicko-Augsburski, s. 417, 422, 425.

16 W. Jemielity, Kontakty religijne katolików przy granicy Królestwa Polskiego i Prus, Studia Teologiczne 17(1999)359-365. 


\section{Rzymskokatolicy i grekokatolicy}

Unici $z$ omawianego terenu należeli do diecezji chełmskiej, a w niej do dekanatu augustowskiego. Cerkwie znajdowały się w sąsiedztwie parafii łacińskich, Rusini i Polacy mieszkali niejednokrotnie w tych samych wsiach. Wierni i duchowni obu obrządków świadczyli sobie religijną pomoc. Proboszczowie łacińscy zapraszali księży unickich na słuchanie spowiedzi wielkanocnej i podczas odpustów. W Wysokiem Mazowieckiem unici odprawiali swoje nabożeństwa w świątyni łacińskiej do czasu wyremontowania własnej. Unicki proboszcz Hodyszewa zapraszał księży łacińskich na doroczne odpusty w miejscowym sanktuarium maryjnym. W latach pięćdziesiątych, a zwłaszcza po powstaniu styczniowym, władze cywilne wyolbrzymiały różnice pomiędzy obu obrządkami. Po kasacie Unii, grekokatolicy szukali pomocy duchowej u księży łacińskich. Chcąc temu przeszkodzić, rząd zniósł parafie łacińskie w Lipsku i Teolinie i często usuwał księży z parafii, na przykład w Adamowiczach w ciągu trzydziestu lat było aż szesnastu proboszczów ${ }^{17}$. Rzymskokatolicy i grekokatolicy spotykali się na modlitwie w sanktuariach maryjnych w Hodyszewie, Krasnymborze, Płonce Kościelnej i Studzienicznej. Do ostatniej miejscowości przybywali licznie także Litwini. Wydaje się, że na omawianym terenie unici i łacinnicy byli sobie duchowo bliscy ${ }^{18}$.

\section{Prawosławni i katolicy}

Można wyróżnić trzy okresy we wzajemnych kontaktach prawosławnych i katolików: przed 1830 r., po powstaniu listopadowym i w drugiej połowie XIX wieku. W pierwszym okresie było niewielu prawosławnych, brakowało cerkwi i duchownych. Zdarzało się, że prawosławni korzystali z posług religijnych u duchownych katolickich. 11 lutego 1835 r. komisja rządowa spraw wewnętrznych i duchownych zabroniła księżom udzielania pomocy prawosławnym, nakazując, by wyznawcy prawosławia udawali się do swoich duchownych. Już 9/21 lipca tego roku komisja rządowa cofnęła zakaz odnośnie spowiedzi i chrztu dzieci, gdy istniało niebezpieczeństwo śmierci, a w pob-

17 W. Jemielity, Dekanat unicki, s. 163.

18 W. Jemielity, Sanktuaria maryjne w diecezji łomżyńskiej, Łomża 1991, s. 13, 55, 95, 179. 
liżu nie znajdował się duchowny ich wyznania. Dnia 12/24 grudnia 1846 r. komisja rządowa powiadomiła biskupów katolickich o wydaniu całkowitego zakazu udzielania przez księży pomocy religijnej prawosławnym. Mieli jej udzielać kapelani wojskowi tam, gdzie nie było proboszcza prawosławnego. Komisja rządowa tłumaczyła, że biskupi prawosławni gotowi byliby przy jąć z bratnią miłością posługi religijne duchownych katolickich, gdyby oni zaraz powiadamiali najbliższego duchownego prawosławnego celem wpisania do ksiąg cerkiewnych daty chrztu i spowiedzi. Ponadto zdarzały się przypadki, że nie istniało zagrożenie dla życia tych osób, a księża świadczyli posługę religijną, nawet nie powiadamiając duchownych prawosławnych. $Z$ tego powodu komisja rządowa podjęła decyzję, by odtąd księża katoliccy żadnemu prawosławnemu i pod jakimkolwiek pozorem nie udzielali żadnych posług religijnych.

Władze cywilne prowadziły kontrolę osób wyznania prawosławnego. Dnia 24 grudnia 1853 r. komisja rządowa spraw wewnętrznych i duchownych poleciła gubernatorom, by powiadamiali duchownych prawosławnych o każdym nowo przybyłym na swój teren wyznawcy prawosławia. Dnia 4/16 sierpnia 1856 r. komisja rządowa przypomniała to rozporządzenie, bowiem arcybiskup warszawski i nowogieorgiewski uskarżał się na brak wiadomości. Gubernator augustowski zwrócił się do wójtów i burmistrzów, by podawali wykazy imienne odrębnie w każdym roku. Konsystorz prawosławny warszawski informował biskupów katolickich, które osoby z ich diecezji przeszły na prawosławie, aby księża nie spełniali wobec nich posług religijnych.

Po powstaniu styczniowym powstało wiele parafii „wyznania greckorosy jskiego". W 1833 r. namiestnik Królestwa Polskiego stwierdził, że księża w ogłoszeniach i dokumentach nazywali prawosławnych schizmatykami, co sprzeciwiało się ukazowi cara i podlegało karze przewidzianej w rozdziale 8, paragrafach 78 i 19. Namiestnik przypomniał oficjalną nazwę --wyznanie greckorosyjskie. Biskup augustowski, Mikołaj Manugiewicz, polecił księżom używać jedynie tego określenia. Katolicy i prawosławni nie kontaktowali się więcej ze sobą na polu religijnym. Nie można stwierdzić między nimi zażyłości ani wrogości ${ }^{19}$.

19 W. Jemielity, Eomżyński Dziekanat, s. 205. 


\section{IV. Żydzi a chrześcijanie}

\section{Służba chrześcijan}

Dnia 14 lutego 1824 r. komisja rządowa spraw wewnętrznych i duchownych powiadomiła biskupów, iż jest rzeczą nieprzyzwoitą, aby chrześcijanie przyjmowali służbę w domach żydowskich. Komisja wysłała uprzednio takie ostrzeżenie do wszystkich władz wojewódzkich i miejskich. W dwanaście dni potem komisja rządowa wyjaśniła, że chrześcijanie mają pozostać w służbie do zakończenia terminu zawartej umowy oraz że chodzi tylko o posługi domowe, a nie o prace w fabrykach i rzemiośle. I znów po następnych kilkunastu dniach komisja skierowała pismo do biskupa Marciejewskiego, w którym stwierdzała, iż w wielu miejscach zrozumiano zakaz niewłaściwie, a nawet że księża źle przedstawiają sprawę z ambon. Nie dozwala się bowiem jedynie prac domowych, można je natomiast podejmować w różnych zakładach. Biskup Marciejewski wyłożył to księżom dokładniej: by chrześcijanie nie trudnili się służbą wewnętrzną, szczególnie przy żydowskich szabasach, rozmaitych zabobonach i zwyczajach. Takich będzie karać policja krajowa, a duchowni odmówią sakramentów do czasu poprawy i porzucenia na zawsze służby. Księża zwracać się będą do biskupa o udzielenie im prawa do rozgrzeszania nieposłusznych ${ }^{20}$.

Szczególny zakaz odnosił się do kobiet piastujących dzieci żydowskie. Namiestnik Królestwa, Paskiewicz, w przepisach dla Żydów z 15 listopada 1847 r. wyraźnie zabronił kobietom chrześcijańskim podejmowania się takiej roli. Zaznaczył jednak, aby zakazu nie ogłaszać w prasie ani z ambony. Gubernatorzy poinformowali o tym naczelników powiatowych, a kancelaria biskupia (konsystorz) duchowieństwo. Konsystorz sejneński dodał od siebie, iż Kościół od dawna zakazywał służby u Żydów, a zwłaszcza karmienia piersią, mianowicie papieże Grzegorz XIII w 1581 r. i Benedykt XIV w 1751 r. Przebywanie z Żydami prowadzi bowiem do lekceważenia przepisów własnej religii i rodzi problemy moralne ${ }^{21}$. Na ile skuteczne były takie zakazy, trudno dociec. W 1873 r. proboszcz z parafii Balwierzyszki wśród wad parafian wymieniał służbę u Żydów tak przez cały rok, jak w dni szabasowe ${ }^{22}$.

20 Archiwum Diecezjalne w Łomży (skrót: ArŁm). Zespół Ogólny (skrót: II), sygn. 32 k. 85, 90, 129, 153; II sygn. 52 k. 41.

21 ArŁm, II sygn. 68 k. 38.

22 ArŁm. Zespół Parafialny (skrót: I), sygn. 18. 


\section{Handel}

W lutym 1824 r. komisja rządowa wyznań religijnych i oświecenia publicznego uznała za rzecz nieprzyzwoitą, aby Żydzi handlowali katolickimi książkami religijnymi. Chodziło o sprzedaż obnośną oraz w sklepach żelaznych lub bławatnych, nie zaś w księgarniach i drukarniach żydowskich. W dwa lata potem ojciec kapucyn powiadomił konsystorz, iż w Łomży starozakonni mają w sklepach różańce, koronki, obrączki, medaliki itp., które lud kupuje. Jest zgrozą dla wiary chrześcijańskiej, pisał, aby tymi przedmiotami mieli handlować Żydzi. Podał nazwisko i adres pewnej kobiety. Konsystorz zwrócił się do komisarza obwodowego, ten zlecił policji skonfiskować paciorki, obrączki itp. Do handlu rzeczami świętymi nawiązywano wielokrotnie. W 1883 r. generał gubernator warszawski wy jaśnił, iż ukaz cesarski z poprzedniego roku wzbraniający niechrześcijanom handlu przedmiotami religijnymi odnosi się tylko do obrazów, medalików, krzyży, różańców, koronek, szkaplerzy itp., nie zaś do książek o treści religijnej23.

Żydzi bywali szynkarzami. W 1816 r. namiestnik Królestwa zakazał im dawać włościanom trunki na kredyt lub za produkty. Groziła za to kara $30 \mathrm{zł}$, za ponowne przewinienie 60 zł, za trzecie - odebranie koncesji. Księża ogłaszali to z ambon przez cztery niedziele. W 1818 r. namiestnik zabronił proboszczom zatrudniać Żydów w swoich karczmach. W 1823 r. namiestnik wyjaśnił, iż osiedlenie się Żydów w dobrach kościelnych nie upoważnia ich do wyrabiania i sprzedaży trunków ${ }^{24}$.

\section{Niepokoje}

W 1801 r. Kamera Białostocka przekazała biskupowi wigierskiemu list królewski w sprawie Żydów. Podczas badań sądowych okazało się, iż część mieszkańców uważa zabicie starozakonnego za mniejsze zło niż zabicie chrześcijanina i sądzi, że za to nie przysługu je kara śmierci. Duchowni mieli w kazaniach pouczyć lud, iż dla wszystkich są jednakowe prawa. Biskup Michał Karpowicz uznał, że treść listu narusza honor duchowieństwa. Stwierdził, że to ktoś złośliwy i niechętny Kościołowi przedstawił rządowi, iż zabicie starozakonnego nie jest tak ciężkim grzechem, podczas gdy on sam od lat dziecinnych nie słyszał, aby zabicie wyznawcy mojżeszowego uszło komuś

\footnotetext{
23 ArŁm, II sygn. 32 k. 90, 129; II sygn. 71 k. 114; II sygn. 313 k. 87.

24 ArŁm, II sygn. 80 k. 35; II sygn. 83 k. 36; II sygn. 53 k. 59; II sygn. 31 k. 97.
} 
bezkarnie. Od króla Kazimierza Wielkiego Żydzi nazywali Polskę swoim rajem. Skoro jednak rząd domaga się, żeby księża mówili wiernym o szacunku dla każdego człowieka, to on wyda taki nakaz ${ }^{25}$.

To, czego obawiali się Prusacy, nastąpiło pod koniec XIX wieku. W latach osiemdziesiątych pogromy przeniosły się z Kiszynia i Odessy do Królestwa Polskiego. W marcu 1881 r. naczelnik powiatu sejneńskiego informował biskupa Piotra Pawła Wierzbowskiego, iż wśród ludu krąży pogłoska, jakoby w pierwszy dzień Wielkanocy miała nastąpić ogólna bójka starozakonnych $\mathrm{z}$ chrześcijanami. Naczelnik powiatu nie widział jeszcze $\mathrm{w}$ tej pogłosce większego zagrożenia spokoju. W tydzień potem gubernator suwalski stwierdził, iż wśród ludu rozchodzą się wieści o rychłym przyjściu Mesjasza i o tym, że gdy się zjawi, starozakonni będą zabijać chrześcijan. Ci ostatni, pragnąc to uprzedzić, zamierzają wyrżnąć wyznawców mojżeszowych. W wielu miejscach już nastąpił popłoch. Zaapelował więc do biskupa, by uspokoił nastroje. 27 maja tego roku biskup Wierzbowski wystosował odezwę adresowaną do duchowieństwa i wiernych. Pisał, iż złowrogie myśli przeniosły się $w$ te strony z Cesarstwa. On sam jest pewien, iż chrześcijanie są posłuszni prawom bożym i ludzkim i nie posuną się do czynów ohydnych. W imię Boże wezwał do miłości wszystkich, niezależnie od wyznania. Księża mieli odczytać z ambon odezwę i szczegółowo wyjaśnić jej treść.

W końcu maja tego roku gubernator suwalski sugerował biskupowi, by w tym roku zaniechać obchodów święta Bożego Ciała i odpustów parafialnych. Biskup był innego zdania, uważał, iż to mogłoby zaostrzyć sytuację. Raczej niech Żydzi pozostaną w domach, zamkną sklepy i karczmy, a gdyby musieli wyjść z domów, niech okazu ją poszanowanie dla obrządku religijnego i zdejmują czapki, co nawet swoim wyznawcom polecali rabini. W parafii Balwierzyszki podczas odpustu doszło jednak do zamieszek. Biskup Wierzbowski winą obarczył władze cywilne, bowiem pomimo zakazu otwierania. sklepów były one czynne, straż ziemska. też nie uczyniła nic, aby pogodzić zwaśnionych. Wkrótce potem biskup Wierzbowski kilkakrotnie wzywał duchowieństwo i wiernych, aby nie ulegali podszeptom złych ludzi i przeciwstawiali się napaściom na starozakonnych. Mimo to w sierpniu 1882 r. doszło do zajść w parafii Prenach: tłum zaatakował Żydów i zniszczył wiele sklepów ${ }^{26}$.

25 ArŁm, II 48 k. 42.

26 ArŁm, II sygn. 71 k. 96, 107; II sygn. 74 k. 2. Przegląd Katolicki 1882, s. 671. 
W 1906 r. wyznawcy mojżeszowi osady Olita powiadomili gubernatora suwalskiego, iż boją się pogromu. Gubernator zwrócił się do administratora diecezji, ks. Józefa Antonowicza, który polecił miejscowemu proboszczowi, aby w najbliższą niedzielę objaśnił $z$ ambony, iż katolicy nawet nie powinni myśleć o biciu współmieszkańców, niszczeniu ich mienia lub znęcania się w jakikolwiek sposób. Ks. Antonowicz dodał, iż to, co stało się w Białymstoku, było złe 27 .

\section{Zmiana wyznania}

\section{Chrzest starozakonnych}

W XIX wieku zmiana religii bądź wyznania była wspólną sprawą Kościoła i rządu. W 1809 r. biskupi Księstwa Warszawskiego powiadomili króla, iż od dawna jedynie urzędy duchowne egzaminowały starozakonnych oraz innych chrześcijan, którzy pragnęli być katolikami. Teraz zadanie to przejęły prefektury i dopiero po liście rekomendacyjnym od nich władza duchowna przeprowadza ostatni, trzeci egzamin. Biskupi proponowali prostszy sposób: w miastach egzamin przez urząd miejski, a po wsiach przez urząd gminny wspólnie z proboszczem miejsca, i następnie odesłanie zainteresowanego do biskupa $^{28}$. Dopiero jednak w 1823 r. zmieniono przepisy. Badanie kandydatów odbywało się w obecności proboszcza i wójta lub burmistrza. Protokół badania przesyłano do komisarza obwodu, ten do komisji wojewódzkiej, która $\mathrm{z}$ kolei zwracała się do konsystorza, by wskazał miejsce, gdzie przyszły neofita miał poznawać zasady wiary ${ }^{29}$.

Kandydat na katolika musiał udowodnić szczerą chęć przyjęcia chrztu, w tym cell odpowiadał na kilkanaście postawionych sobie pytań. Następnie przygotowywał się w klasztorze lub u proboszcza. W czasie trwania nauki za jego utrzymanie płacił rząd. Niektórzy starozakonni przerywali naukę, a niekiedy odchodzili nawet po otrzymaniu chrztu ${ }^{30}$. Obrzęd chrztu odbywał

27 ArŁm, I sygn. 346 k. 161.

28 ArŁm, II sygn. 503 k. 29.

29 ArŁm, II sygn. 84 k. 11; II sygn. 31 k. 148; II sygn. 53 k. 28.

30 II sygn. 5 k. 142, 162; II sygn. 6 k. 51; II sygn. 32 k. 167, 170; II sygn. 54 k. 76, 82, 83; II sygn. 58 k. 9, 16; II sygn. 59 a k. 104. Archiwum Kapucynów w Łomży, Akta od 1814 . 
się uroczyście, z udziałem znaczących osób danego miasta. Żydzi zmieniali imię, a do 1850 r. i nazwisko ${ }^{31}$.

$\mathrm{Na}$ omawianym terenie właściwie nie było mahometan. A jednak w 1822 r. pewna kobieta poprosiła o chrzest. Wójt gminy spisał protokół i przesłał do komisarza obwodowego. Ten posiadal jedynie przepisy dotyczące starozakonnych, wszakże uznał, że mahometanka też musi ukrywać swoje zamiary przed współwyznawcami oraz że powinna nauczyć się zasad nowej wiary. Zwrócił się więc do biskupa, by wskazał dla niej odpowiednie miejsce celem przygotowania do chrztu ${ }^{32}$.

\section{Przejście ewangelików na katolicyzm}

W 1838 r. biskup Paweł Straszyński pozwolił przyjąć do Kościoła Karolinę Zaborowską z parafii Sylwanowce, polecając na spowiedzi rozgrzeszyć ją $z$ herezji. W parafii Piekuty Katarzyna Zamulowa złożyła wyznanie wiary wobec miejscowego proboszcza i ludu zgromadzonego na nabożeństwie niedzielnym. Podobnie w parafii Kuczynie - Karol Koch, w parafii Dąbrowa Wielka - Wilhelmina Galinat itd. Nic nie wspominano o przygotowaniu katechetycznym kandydatów. Autor nie spotkał żadnych rozporządzeń kościelnych i cywilnych w tym względzie. Jedynie w 1838 r. biskup Straszyński informował księży, iż mają go powiadamiać o pragnących przejść z protestantyzmu, on zezwoli na rozgrzeszenie $z$ błędów, po fakcie chrztu proboszczowie złożą sprawozdanie ${ }^{33}$.

\section{Katolicy i prawosławni}

W diecezji augustowskiej czyli sejneńskiej z katolicyzmu na prawosławie przeszło osób: w 1852 r. $-5,1853$ r. $-1,1854$ r. $-5,1855$ r. $-1,1856$ r. -2 , 1857 r. - 2; głównie czyniły to kobiety, poślubiając mężczyzn tego wyznania. Więcej przejść było na przełomie stulecia. W guberni łomżyńskiej: w parafii Świętej Trójcy w Łomży 1899 r. - 4, 1913 r. - 5; parafii Hodyszewo 1912 r. - 1; parafii Łapy 1912 r. - 6; parafii Ostrów 1914 r. - 1. Przejścia z prawo-

31 ArŁm, II sygn. 32 k. 170, 172; II sygn. 66 k. 46; II sygn. 68 k. 46, 103; II sygn. 69 k. 10; II sygn. 495 k. 285; II sygn. 505 k. 23. Por. W. Jemielity, Kontakty religijne katolików i żydów w Królestwie Polskim, w: Maqom R. 31998 Nr 1(5). Instytut dialogu katolicko-judaistycznego Akademii Teologii Katolickiej w Warszawie, s. 57-82.

32 ArŁm, II sygn. 54 k. 87.

33 W. Jemielity, Kościół Ewangelicko-Augsburski, s. 421. ArŁm, II sygn. 58 k. 16. 
sławia na katolicyzm były liczniejsze, ale dopiero po ukazie tolerancyjnym 1905 r. i dotyczyło to głównie byłych unitów: Łomża 1911 r. - 56; Hodyszewo 1910 r. - 330, 1911 r. - 2; Łapy od 1905 r. - 1911 r. - 24; Grajewo 1911 r. - 8; Ostrów 1911 r. - 16, 1913 r. - 1, 1914 r. - 4 osoby ${ }^{34}$.

W niektórych latach w czasopismach kościelnych podawano liczby starozakonnych i ewangelików dla całego Królestwa Polskiego. Starozakonnych przeszło na katolicyzm: 1843 r. $-114,1845$ r. $-128,1847$ r. $-181,1848$ r. $-112,1849$ r. $-90,1850$ r. $-32,1851$ r. $-63,1852$ r. $-45,1854$ r. -50 , 1855 r. $-59,1856$ r. $-48,1857$ r. $-20,1861$ r. -26 ; ewangelików: 1848 r. - 73, 1849 r. $-94,1850$ r. $-65,1851$ r. $-45,1852$ r. $-60,1854$ r. -72 , 1855 r. $-39,1856$ r. $-18,1857$ r. $-76,1861$ r. -4 osoby ${ }^{35}$.

Do Kodeksu Napoleona rejestracja urodzeń, ślubów i zgonów miała cele wyznaniowe. Od 1 maja 1808 r. w Księstwie Warszawskim upaństwowioną rejestrację aktów stanu cywilnego powierzono urzędnikom świeckim, a duchowni nadal prowadzili księgi kościelne i tymczasowo cywilne. W miastach funkcje te pełnili burmistrzowie lub inne osoby, po wsiach proboszczowie, a gdzie było dużo Żydów - organiści lub inne osoby. W rok potem król Fryderyk August mianował duchownych na stałe do prowadzenia ksiąg. Spisywali oni także akta starozakonnych i przedstawicieli innych wyznań. W 1808 r. wyraźnie zaznaczono, iż urzędnicy nie mogą prowadzić osobnych ksiąg aktów żydowskich, a tylko odrębne metryki dla każdego wyznania, aby ułatwić robienie statystyk. Istotną zmianę wprowadził sejm w 1825 r. Dla wyznań chrześcijańskich połączył akta cywilne $z$ metrykami kościelnymi i zlecił spisywanie aktów przełożonym urzędów parafialnych. Natomiast dla wyznania mojżeszowego i innych wyznań niechrześcijańskich sejm ustanowił urzędników w poszczególnych okręgach. Sejm usankcjonował więc podział obywateli według wyznań3 ${ }^{36}$. Może przyczynił się do tego opór niektórych grup ludności. W województwie płockim wielu starozakonnych nie spisywało aktów urodzeń, ślubów i zgonów. W 1817 r. rząd zagroził im karami, za przewinienia poszczególnych członków odpowiedzialnością obarczył kahały; należało uzupełnić akta za ubiegłe lata ${ }^{37}$.

34 W. Jemielity, Łomżyński Dziekanat, s. 190, 206.

35 „Pamiętnik Religijno-Moralny” t. 7, s. 274; t. 9, s. 368; t. 23, s. 646; t. 25, s. 540; t. 27 , s. 547 ; t. 31 , s. 297 ; seria II t. 1 , s. 207 ; t. 2 , s. 550 ; t. 10 , s. 307.

36 W. Jemielity, Akta stanu cywilnego w Księstwie Warszawskim i Królestwie Polskim, Prawo Kanoniczne 38(1995)163n. ArŁm, II sygn. 79 k. 154.

37 ArŁm, II sygn. 80 k. 41, 139. 


\section{Małżeństwa mieszane}

\section{Prawosławnych z katolikami}

Przy zawieraniu małżeństw mieszanych strona prawosławna była uprzywilejowana. Prawo o małżeństwie z 1836 r. paragraf 202 stanowiło: „Wolno jest przyszłym małżonkom żądać dopełnienia ślubu religijnego i przez duchownego strony, która nie należy do wyznania greckorosyjskiego, skoro już dopełniony był obrzęd przez duchownego tejże religii". Dzieci z małżeństw mieszanych miały być wychowywane $\mathrm{w}$ prawosławiu, zgodnie $\mathrm{z}$ ustawą z 21 stycznia / 6 lutego 1829 r. W 1850 r. arcybiskup Fijałkowski wraz $\mathrm{z}$ innymi biskupami obecnymi w Warszawie zakwestionował prawo o małżeństwie z 1836 r., powołu jąc się na kodeks karny z 1848 r. Car polecił surowo upomnieć biskupów, gdyż: zebranie odbyło się wbrew ustawie z 6/18 marca 1817 r., która zabraniała wspólnych zebrań biskupów bez uprzedniej zgody rządu; kodeks z 1848 r. nie znosił ustawy z 1836 r., tylko wyznaczał kary za wykroczenia przeciw dotychczasowemu porządkowi; ustawa z 1829 r. wskazywała na wyłączne uprawnienia biskupów prawosławnych w tych sprawach. Po powstaniu styczniowym przybyło do Królestwa wielu urzędników i policjantów. Niektórzy traktowali swój pobyt jako tymczasowy i nie zakładali rodzin, inni żenili się z miejscowymi katoliczkami. W 1890 r. w Łomży było czternaście takich małżeństw. W 1911 r. proboszcz z Ostrowi stwierdził, iż wielu mężczyzn ożeniło się z kobietami innego wyznania, i te nie przechodziły na prawosławie ${ }^{38}$.

\section{Ewangelików z katolikami}

Przy tych małżeństwach mieszanych głoszono zapowiedzi w świątyni katolickiej i ewangelickiej, a ceremonia ślubu odbywała się w parafii narzeczonej. W 1842 r. zaistniał miejscowy konflikt. Oto proboszcz z Raczek udzielił ślubu Ludwice Stelmachowskiej wyznania ewangelickiego i Karolowi Czarneckiemu ze swojej parafii. Pastor zaskarżył go o przekroczenie prawa krajowego. Władza cywilna i biskup upomnieli proboszcza z Raczek. W tymże roku Gottlib Rudatys chciał poślubić Annę Paraszkiewiczównę i złożył deklarację, że nie będzie jej wzbraniał spełniać praktyki i wychowy-

38 W. Jemielity, Eomżyński Dziekanat, s. 190, 206. 
wać dzieci po katolicku, ale sam nie zamierzał opuszczać wyznania ewangelickiego. Biskup Straszyński odmówił zezwolenia na to małżeństwo. Wyjaśnił, iż skończyły mu się upoważnienia dane przez Stolicę Apostolską, miał też wątpliwości, czy Anna, żyjąc w rodzinie luterańskiej, zdoła wypełnić swoje zobowiązania religijne. Niekiedy ślub łączył się ze zmianą wyznania. W 1839 r. uczynił tak Wilhelm Bronowicz, pięć lat potem Mateusz Wyłucki. W drugim przypadku biskup Straszyński wyjaśnił, iż Wyłucki, już jako katolik, nie potrzebuje głosić zapowiedzi przed pastorem.

W 1838 r. proboszcz z Szumowa podał, że mieszkańcy Srebrnego Borku chrzcili dzieci i zawierali małżeństwa w jego świątyni. Trzeba tu uwzględnić przepisy prawa cywilnego. Ewangelicy tej wsi nie mieli w pobliżu swojego duchownego, dla nich urzędnikiem stanu cywilnego był proboszcz katolicki, i odwiedzali go w tym charakterze ${ }^{39}$.

\section{Szkolnictwo}

Do 1864 r. szkoły elementarne były przy parafiach. Po powstaniu styczniowym opiekę nad nimi przejęły gminy. W 1875 r. zmieniono nazwy szkół wyznania katolickiego i prawosławnego, wprowadzając nazwy: szkoła wiejska, szkoła gminna i szkoła miejska. Ewangelickie kantoraty i szkółki żydowskie pozostały przy dawnych nazwach. W 1872 r. wprowadzono naukę czytania i pisania po rosyjsku, dwa lata potem w Warszawskim Okręgu Naukowym przy jęto ustalenia, jakie obowiązywały formalnie jedynie na obszarze Cesarstwa. W 1875 r. zobowiązano do nauczania wszystkich przedmiotów po rosyjsku, z wyjątkiem języka polskiego i religii. Język rosyjski był więc wspólny dla dzieci wszystkich wyznań i narodowości. Prywatne nauczanie było zakazane, wyjątek zrobiono dla kantoratów ewangelickich i chederów żydowskich, o charakterze wybitnie religijnym. W 1871 r. w guberni suwalskiej było 19 kantoratów, 1906 r. tylko 4; w guberni łomżyńskiej w 1876 r. 12, 1906 r. 2 kantoraty. Chederów było wszędzie dużo.

W województwie augustowskim znajdowały się jedynie gimnazja męskie w Łomży i Suwałkach. Po powstaniu styczniowym: w guberni łomżyńskiej gimnazjum męskie i gimnazjum żeńskie w Łomży, w guberni suwalskiej gimnazjum męskie w Suwałkach i Mariampolu, gimnazjum żeńskie w Suwałkach i seminarium nauczycielskie w Wejwerach; po 1905 r. powstało jeszcze kilka

39 W. Jemielity, Kościót Ewangelicko-Augsburski; s. 421. 
szkół średnich. W szkołach elementarnych uczyły się przeważnie dzieci jednej narodowości i wyznania, ale nie było to regułą. Na przykład w powiecie makowskim w Drążdżewie uczyło się 65 katolików i 4 żydów, w Krasnosielcu - 192 katolików, 2 ewangelików i 4 żydów, w Różanie - 50 katolików, 6 prawosławnych, 3 ewangelików i 3 żydów. W szkołach średnich było inaczej. W 1890 r. w gimnazjum męskim w Łomży uczniów wyznania katolickiego było 251 , prawosławnego - 62 , mojżeszowego - 17, luterańskiego - 7; w gimnazjum żeńskim w Łomży: katolickiego - 95, prawosławnego - 85, luterańskiego - 13, mojżeszowego - 7. W 1900 r. w Łomży wymieniono narodowości: w gimnazjum męskim Polaków było 260, Rosjan 94, Żydów 38, Niemców 8; w 1902 r. w gimnazjum żeńskim tamże: Polek 129, Rosjanek 84, Żydówek 30, Niemek 10. Przyszła inteligencja kształciła się razem, niezależnie od wyznania i narodowości. Po 1905 r. Polacy chętniej korzystali ze szkół prywatnych z polskim językiem nauczania ${ }^{40}$.

\section{Cmentarze}

Przez stulecia zmarłych grzebano wokół kościołów. Pod koniec XVIII wieku zaczęto przenosić cmentarze grzebalne poza miasto i wieś, co upowszechniło się w kolejnym stuleciu. Pod względem prawnym najważniejsze było postanowienie Rady Administracyjnej Królestwa o cmentarzach z 31 maja/12 czerwca 1846 r. W obrębie niektórych parafii katolickich mieszkali prawosławni i protestanci. W $1834 \mathrm{r}$. rząd polecił wyznaczyć na cmentarzach katolickich „tam gdzie zachodzi potrzeba” oddzielne miejsce dla niekatolików. W 1842 r. rozciągnięto to na wszystkie cmentarze katolickie. Pięć lat potem stwierdzono, że niektóre parafie niechętnie przyjmowały innych wyznawców, a przecież powinny wydzielić jakąś część cmentarza. W $1857 \mathrm{r}$. władze cywilne nakazały wyodrębnić na stałe część cmentarza, gdyż dotąd grzebano prawosławnych nie zawsze na właściwym miejscu. Osiem lat wcześniej w parafii Rajgród dwaj włościanie pochowali zmarłego wyznania prawosławnego i przyszli do proboszcza spisać akt zejścia. Proboszcz kazał przenieść ciało na inne miejsce i dokonał wyświęcenia cmentarza. Jeszcze w 1911 r. generał gubernator warszawski poinformował biskupów, że w jednej parafii odmówiono prawosławnemu pogrzebu. Powołał się na postano-

40 W. Jemielity, Szkolnictwo w guberni suwalskiej, Suwałki 1997, s. 17, 109, 117; tenże, Szkolnictwo w guberni łomżyńskiej, Warszawa 1994, s. 46, 111, 113, 118, 121. 
wienie Rady Administracyjnej Królestwa z 1846 r., że nie może to być miejsce wspólne $z$ dziećmi nie ochrzczonymi i samobójcami.

Protestanci częściej posiadali własne cmentarze, ale korzystali i z katolickich. W 1854 r. luteranin pochował żonę na cmentarzu w Bargłowie. Następnego dnia parafianie przenieśli ciało „na właściwe miejsce”. W końcu stulecia w tej parafii mieszkało szesnaście rodzin luterańskich. Wchodzili wspólną bramą i przez cmentarz katolicki szli do swojego. W 1890 r. wykonano nową bramę i ogrodzono tylko cmentarz katolicki. Luteranie zanieśli skargę do naczelnika powiatu, który poradził im, aby ogrodzili swoją część i zrobili drugą bramę. We wsi Lekajcie wzniesiono kaplicę do spowiadania w okresie wielkanocnym chorych i starych. Proboszcz chciał poświęcić tę kaplicę, ale przy niej pochowano protestanta. Zwrócił się do biskupa z pytaniem, jak ma postąpić. Ten polecił proboszczowi dokonać poświęcenia, ale uczynić to po cichu, by nie urazić protestantów ${ }^{41}$.

Powyżej omówiono wyznawców żyjących w rozproszeniu. Parafia prawosławna w Łomży miała własny cmentarz, obok katolickiego. W 1887 r. powiększono obszar cmentarza i otoczono murem. W Grajewie do 1892 r. grzebano wiernych wyznania prawosławnego na cmentarzu luterańskim, potem otwarto własny. W Ostrowi był własny, w Łapach wspólny z luteranami, w Kolnie wydzielono miejsce na cmentarzu katolickim ${ }^{42}$. W Łomży cmentarz dla ewangelików znajdował się obok katolickiego i był oddzielony murem. W Jasienicy ewangelicy mieli wydzielone miejsce na cmentarzu katolickim, a własne cmentarze w Paproci Dużej, Marianowie i Srebrnym Borku; w ostatniej miejscowości dla mieszkańców jednej wsi ${ }^{43}$.

Cmentarze żydowskie zawsze były w miejscu odrębnym, nie połączone z chrześcijańskimi. W 1858 r. w obwodzie łomżyńskim były 44 cmentarze: 44 katolickię, 1 unicki, 1 ewangelicki i 13 mogiłek żydowskich. Te ostatnie znajdowały się w miasteczkach i osadach, w których były równocześnie i parafie katolickie ${ }^{44}$.

We wschodnim rejonie Królestwa Polskiego liczebnie przeważali katolicy, na Suwalszczyźnie narodowości litewskiej, a w Łomżyńskiem narodowości polskiej. Liczni byli Żydzi, niewielki procent Niemców, nieco Rusi-

41 W. Jemielity, Cmentarze $w$ diecezji augustowskiej czyli sejneńskiej, Prawo Kanoniczne 37(1994)268, 272.

42 W. Jemielity, Eomżyński Dziekanat, s. 201.

43 W. Jemielity, Kościót Ewangelicko-Augsburski, s. 420.

44 Archiwum Państwowe w Eomży. Zespół naczelnika powiatu łomżyńskiego 18161866, sygn. 10 k. 1084. 
nów, po powstaniu styczniowym wzmógł się napływ Rosjan. W końcu XIX wieku wśród rzymskokatolików ujawniły się napięcia na tle używania języka polskiego i litewskiego w nabożeństwach. Kontakty katolików obrządków łacińskiego i greckiego przebiegały na ogół poprawnie. Obcość panowała między katolikami i prawosławnymi. Niemcy wyznania katolickiego wtapiali się w miejscową ludność, inaczej niż ci wyznania protestanckiego. Starozakonni wyraźnie różnili się od chrześcijan. Wyznanie pokrywało się w zasadzie z narodowością, a zmiana wyznania łączyła się z opuszczeniem swojej nacji. W tym względzie rząd wydawał szczegółowe przepisy, głównie dla Żydów. Takich przejść z mozaizmu na katolicyzm było niewiele, także wzajemnie między wyznaniami chrześcijariskimi. Pomimo drobnych napięć narodowości i wyznania we wschodnim rejonie Królestwa Polskiego współistniały ze sobą poprawnie ${ }^{45}$.

\title{
COEXISTENCE OF NATIONS AND RELIGIO ON THE EASTERN AREAS OF THE CONGRESS KINGDOM OF POLAND
}

\author{
SUMMARY
}

Augustów County was one of the eight Congress Kingdom of Poland. In the year 1866 it was devided into Łomża and Suwałki guberniyas. Coexistance of different nations and religions on this area is discussed in the following work. As regards nations, there lived the Polish, Lithuanians, White Russians, Russians, Germans and Jews, howeher as it regards religions there lived: Roman - Catholics, Greek -Catholics, members of the Orthodox Church, Evangelical as well as Jewish faith.

In the end of the previous century one could observe differences as it comes to the use of the Polish and Lithuanian languages during the service in the Roman Catholic Church. Contacts of the Greek Catholics and the Catholics of the Latin rite were proper. The feeling of unfriendliness could be observed between Catholics and members of the Ortodox Church and

45 W 2000 roku ukaże się Księga Pamiątkowa 80-lecia Seminarium Duchownego w Eomży. Znajdzie się tam pełny wykaz publikacji autora niniejszego opracowania. 
to a smaller extent to Evangelics. There was a distinc difference between the Christians and members of the Jewish fajth who made people feel great antipathy to them.

As a rule religion agreed with the nationality, any change of the religion meant abandonment of his own nation. The Government issued a lot of regulations and laws as regards the latter, mostly for the Jewish. Conversion from Mosaism to Catholic religion was not wery popular, the same was between Christian religions. This conversion was mostly made due to mixed marriages.

Until the time of January Uprise each religion had its own elementary schools. After the year 1864 schools were overtaken by the civil parishes which introduced gradually Russian language as the common one for all of them. 